\title{
Effects of different frozen temperatures of pork sausage batter on quality characteristics of reduced-salt sausages using pre-rigor muscle
}

\author{
Geon Ho Kim ${ }^{1}$ and Koo Bok Chin ${ }^{1 \text { ** }}$
}

\author{
* Corresponding Author: Koo Bok Chin \\ Tel: +82-62-530-2121, Fax: +82-62-530-2129, \\ E-mail: kbchin@chonnam.ac.kr \\ ${ }^{1}$ Department of Animal Science, Chonnam \\ National University, Gwangju 61186, Korea \\ ORCID \\ Geon Ho Kim \\ https://orcid.org/0000-0002-4700-4485 \\ Koo Bok Chin \\ https://orcid.org/0000-0002-8062-6331
}

Submitted Sept 13, 2021; Revised Oct 27, 2021; Accepted Dec 22, 2021
Objective: The objective of this study was to evaluate quality characteristics of reduced-salt pork sausage (PS) using pre-rigor muscle compared to those of regular-salt PS. In addition, effects of freezing on sausage batter with different temperatures $\left(-30^{\circ} \mathrm{C}\right.$ vs $\left.-70^{\circ} \mathrm{C}\right)$ on quality characteristics of both sausage batter and cooked sausages during frozen storage were observed.

Methods: Pre-rigor and post-rigor pork hams were used to manufacture low-fat sausages. Sausages using post-rigor (Post) muscle were manufactured at a salt level of $1.5 \%$, whereas those with pre-rigor (Pre) muscle were processed at salt level of $1.0 \%$. After these muscles were made at two salt levels (1.5\% salt, Post-rigor; $1.0 \%$ salt, Pre-rigor), Sausage batters were stored at two frozen temperatures $\left(-30^{\circ} \mathrm{C}\right.$ vs $\left.-70^{\circ} \mathrm{C}\right)$. During storage for $12 \mathrm{wks}$, they were measured for physicochemical and textural properties every 4 wks up to 12 wks.

Results: $\mathrm{pH}$ values and temperatures of sausage batter of pre-rigor muscle were higher than those of post-rigor muscle regardless of the frozen temperature. The lightness and yellowness values of batter at the initial storage were the highest during storage. For PS, there were no differences in most parameters measured among all treatments. However, expressible moisture values (\%) of Pre-30 and Pre-70 were lower than those of Post-30 $(\mathrm{p}<0.05)$.

Conclusion: Regardless of frozen temperature during storage, quality characteristics of pre-rigor PS with salt level of $1.0 \%$ salt were similar to those of post-rigor PS with salt level of $1.5 \%$. By using the pre-rigor muscle, salt content could be reduced by one third of the regular-salt level (1.5\%) of post-rigor muscle.

Keywords: Pre-rigor Muscle; Pork Sausage; Quality Characteristics; Reduced-salt

\section{INTRODUCTION}

Sodium chloride (Salt, $\mathrm{NaCl}$ ) is a key ingredient that performs many important functions in meat products. It is an important factor that can inhibit growth of microorganisms by decreasing water activity [1]. Since salt can inhibit the growth of microorganisms and extend the shelf-life, it is considered as an important food preservative for food safety [2]. In addition, it is essential for developing flavor of meat products [2]. Protein solubility and extractability can also be increased by the addition of salt [3]. Although salt plays a variety of key roles in meat product manufacturing, when excessive amount of salt is consumed, blood volume and blood pressure may increase, leading to cardiovascular diseases or high blood pressure [4]. Despite the need to the reduction of salt, it might cause undesirable quality of meat products. Therefore, strategies for development of acceptable reduced-sodium meat products are highly needed.

Hot boning is a kind of deboning method to separate the muscle when the carcass still 
has a high temperature, unlike the normal deboning method. Compared to post-rigor muscle, pre-rigor one had better functionalities such as extractability of myofibirillar proteins, binding ability, and water-holding capacity (WHC), resulting in the development of reduced-sodium meat products by improving the undesirable functionalities of those due to the reduction of salt. Puolanne and Terrell [5] reported that emulsified sausage using pre-rigor muscle maintained physicochemical and sensory properties even if the addition level of salt is reduced. In addition, Claus and Sørheim [6] reported that $\mathrm{pH}$ values of beef patty manufactured with pre-rigor muscle had better protein solubility, cohesiveness, and chewiness with a lower cooking loss than those of post-rigor one due to higher $\mathrm{pH}$ of raw meat.

The use of pre-rigor muscle for the manufacture of sausage might be compensated for defects of low or reducedsodium sausages, even when the sausage is manufactured with frozen-stored sausage batter. Since the correlation between high $\mathrm{pH}$ and functionalities are highly associated with processing aptitude of pre-rigor muscle, the application of frozen storage of sausage batter could be applicable. Thus, physicochemical properties of sausage batter as affected by different frozen temperatures and time should be determined to confirm the potential use of frozen storage. Thus, the objective of this study was to evaluate quality characteristics of pork sausages (PS) manufactured with pre-rigor muscle for the development of reduced-salt sausages. In addition, whether frozen storage at two different temperatures $\left(-30^{\circ} \mathrm{C}\right.$ vs $-70^{\circ} \mathrm{C}$ ) of reduced-salt PS using pre-rigor muscle could maintain quality characteristics during $12 \mathrm{wks}$ (4 wks interval) of frozen storage was also determined.

\section{MATERIALS AND METHODS}

\section{Experimental design}

Table 1 shows ingredients added and formulation of manufactured PSs for this study. Two rigor states (pre-rigor vs post-rigor) of raw meat and different additional levels of salt (1.0\% for pre-rigor muscle and $1.5 \%$ for post-rigor one) of sausage batter were used for the quality of PS. Sausages using post-rigor muscle were prepared by adding $1.5 \%$ salt as a reference, whereas others were manufactured using pre-rigor one with $1.0 \%$ salt as a treatment. Prepared sausage batters, which were stored frozen at two different frozen temperatures $\left(-30^{\circ} \mathrm{C}\right.$ vs $\left.-70^{\circ} \mathrm{C}\right)$, were investigated the quality characteristics of PS. Therefore, there were four treatments: Post-30 (Post-rigor, $1.5 \%$ salt, $-30^{\circ} \mathrm{C}$ ), Post-70 (Post-rigor, $1.5 \%$ salt, $-70^{\circ} \mathrm{C}$ ), Pre-30 (Pre-rigor, $1.0 \%$ salt, $-30^{\circ} \mathrm{C}$ ), and Pre-70 (Prerigor, $1.0 \%$ salt, $\left.-70^{\circ} \mathrm{C}\right)$.

\section{Preparation for sausage manufacture}

Fresh pork hams of castrated three-way crossbreeding pig
Table 1. Formulation of pork sausages with different salt level, rigor state and frozen conditions

\begin{tabular}{lcccc}
\hline \multirow{2}{*}{ Ingredients (\%) } & \multicolumn{4}{c}{ Treatment } \\
\cline { 2 - 5 } & Post-30 & Post-70 & Pre-30 & Pre-70 \\
\hline Meat & 80.0 & 80.0 & 80.0 & 80.0 \\
Water & 18.5 & 18.5 & 18.5 & 18.5 \\
Non meat ingredients & 2.00 & 2.00 & 2.00 & 2.00 \\
$\quad$ Sodium chloride & 1.30 & 1.30 & 0.80 & 0.80 \\
Sodium tripolyphosphate & 0.40 & 0.40 & 0.40 & 0.40 \\
Sodium erythorbate & 0.05 & 0.05 & 0.05 & 0.05 \\
Cure blend & 0.25 & 0.25 & 0.25 & 0.25 \\
Total & 100.5 & 100.5 & 100.0 & 100.0 \\
\hline
\end{tabular}

1) Cure blend consisted of $93.75 \%$ of salt and $6.25 \%$ of sodium nitrite.

(Yorkshire $\times$ Landrace $\times$ Duroc, Korean, 1st grade) were purchased from a local meat market (Hyundai distribution, Gwangju, Korea) and used to manufacture PSs. Post-rigor muscle (slaughtered and stored for more than $24 \mathrm{hrs)} \mathrm{and}$ pre-rigor muscle (less than $1 \mathrm{~h}$ after slaughtering) were prepared for manufacturing sausages. After external fat and connective tissues were removed, they were comminuted with curing agent in a meat chopper (M-12S; Hankook Fujee Industries Co., Ltd, Hwaseong, Korea) to manufacture sausages.

Raw meat and ice water were mixed with a grinder (Crypto peerless K55; DITO SAMA, Birmingham, France) for $30 \mathrm{~s}$. Curing agents including salt, sodium nitrite, sodium erythorbate, and sodium phosphate were mixed for $1 \mathrm{~min}$ with ground pork ham and ice water. The remained ice water was added and ground twice for $30 \mathrm{~s}$ each to make sausage batters which were stored either at $-30^{\circ} \mathrm{C}$ or $-70^{\circ} \mathrm{C}$ for $12 \mathrm{wks}$ in a freezer. Frozen sausage batter were thawed at $10^{\circ} \mathrm{C}$ in a refrigerator one day ahead of time at the processing day. They were stuffed into polyvinylidene chloride (PVDC), cooked in water bath (WB-22; Daihan Scientific Co., Ltd., Seoul, Korea) at $75^{\circ} \mathrm{C}$ for 30 min to reach an internal temperature of $71^{\circ} \mathrm{C}$, and then cooled down in an ice water.

\section{Experimental methods}

Determination of $\mathrm{pH}$ and color: The $\mathrm{pH}$ was measured with a solid pH-meter (Model 340; Metter-Toledo, Schwarzenbach, Switzerland). Mean $\mathrm{pH}$ values were calculated from five times for each sample. Color measurements including lightness $\left(\mathrm{CIE} \mathrm{L}^{*}\right)$, redness $\left(\mathrm{CIE} \mathrm{a}^{\star}\right)$, and yellowness $\left(\mathrm{CIE} \mathrm{b}^{\star}\right.$ ) of the cross section of each sausage sample were measured by a CIE color meter (CR-10; Minolta Co. LTD, Tokyo, Japan). Results were expressed as the calculated average of values measured five times (CIE values of the standard plate were $\mathrm{L}^{*}=94.8, \mathrm{a}^{*}=1.0$, and $\left.\mathrm{b}^{*}=0.1\right)$.

Protein solubility: A $30 \mathrm{~g}$ of sausage batter and $90 \mathrm{~mL}$ salt

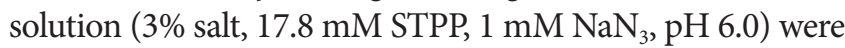
homogenized for $30 \mathrm{~s}$. After the mixture was stored in a re- 
frigerator for $1 \mathrm{hr}$ to extract the protein, the mixture was centrifuged at $12,000 \times \mathrm{g}$ for $1 \mathrm{hr}$. Crude protein content (\%) in the supernatant of the centrifuged sample was determined with the Kjeldahl method. Protein solubility was calculated as follows:

$$
\begin{aligned}
& \text { Protein solubility }(\%) \\
& =\frac{(\text { Protein content of supernatant }) \times 4}{\text { Protein content of sausage batter }} \times 100
\end{aligned}
$$

Texture profile analysis: Texture profile analysis was performed to determine the hardness (gf), springiness ( $\mathrm{mm}$ ), chewiness, and cohesiveness using an Instron Universal Machine (Model 3344; Canton, MA, USA). A load cell of $50 \mathrm{~kg}$ was equipped with a compression probe. A two-bite test was conducted at a cross speed of $300 \mathrm{~mm} / \mathrm{min}$. These results were expressed as the average of values measured 10 times.

Cooking loss: Cooking loss (CL, \%) of a cooked sausage was measured based on the weight of the sausage before and after cooking using the formula shown below:

$$
\begin{aligned}
& \text { Cooking loss }(\%) \\
& =\frac{(\text { Sample weight before cooking }- \text { Sample weight after cooking })}{\text { Sample weight before cooking }} \\
& \quad \times 100
\end{aligned}
$$

Expressible moisture: Expressible moisture (EM, \%) of sausage was measured with the centrifugation method. Briefly, PS samples wrapped with filter paper (Whatman \#3; GE healthcare, Little Chalfont, UK) were centrifuged at 1,660×g for $15 \mathrm{~min}$. The EM (\%) released from each sample wrapped with the filter paper was measured and derived using the following formula:

$$
\begin{aligned}
& \text { Expressible moisutre }(\%) \\
& =\frac{\text { Expressible water weight of filter paper }}{\text { Sample weight }} \times 100
\end{aligned}
$$

Thiobarbituric acid reactive substances: Thiobarbituric acid reactive substances (TBARS) was measured the amount of malondialdehyde (MDA) which reacted with thiobarbituric acid (TBA) in sausage according to the method of Sinnhuber and $\mathrm{Yu}$ [7]. Briefly, a mixture of TBA solution $(3 \mathrm{~mL})$ and homogenized sample $(2 \mathrm{~g})$ was mixed with TBA solution $(17 \mathrm{~mL})$ and heated in a water bath (Whatman \#3; GE healthcare, UK) at $100^{\circ} \mathrm{C}$ for $30 \mathrm{~min}$. Then, each sample $(5 \mathrm{~mL})$ and chloroform $(5 \mathrm{~mL})$ were mixed and centrifuged at $1,660 \times \mathrm{g}$ for $5 \mathrm{~min}$. The supernatant of the centrifuged sample $(3 \mathrm{~mL})$ was then mixed with petroleum ether $(3 \mathrm{~mL})$ and centrifuged again at $1,660 \times \mathrm{g}$ for $10 \mathrm{~min}$. Absorbance of reactive substance in the lower layer was then measured with a spec- trophotometer (Model UV-1601; Shimadzu, Kyoto, Japan) at wavelength of $532 \mathrm{~nm}$. TBARS values were derived with the following formula.

$$
\begin{aligned}
& \text { TBARS value (mg of MDA } / \mathrm{kg} \text { of sample) } \\
& =\frac{\text { Absorbance value } \times 9.48}{\text { Sample weight }}
\end{aligned}
$$

Volatile basic nitrogen: Volatile basic nitrogen (VBN) values were measured using the method of Conway [8] to determine protein degradation. After a homogenized sample was mixed with $9 \mathrm{~mL}$ of double distilled (dd)-water using a homogenizer (T-25 basic; IKA Labortechnik, Staufen, Germany) for $1 \mathrm{~min}$, the mixture was then filtered using a filter paper (Whatman \#2; GE healthcare, UK). And then $1 \mathrm{~mL}$ of the sample was dispensed into the outer chamber of a Conway cell and $1 \mathrm{~mL}$ of a $0.01 \mathrm{~N}$ boric acid solution and $50 \mu \mathrm{L}$ of an indicator $(0.066 \%$ methylene red $+0.066 \%$ bromocresol green) were dispensed into the inner chamber. Then, $1 \mathrm{~mL}$ of saturated $\mathrm{K}_{2} \mathrm{CO}_{3}$ solution (50\%) was injected into the outer chamber. Conway cell was quickly sealed, horizontally agitated, and incubated at $37^{\circ} \mathrm{C}$ for $120 \mathrm{~min}$. After incubation, $0.01 \mathrm{~N} \mathrm{HCl}$ solution was titrated to the sample. The VBN value was then determined using the following formula.

$$
\begin{aligned}
& \text { VBN value }(\mathrm{mg} \%) \\
& =\frac{\text { Titrated amount of } 0.01 \mathrm{~N} \mathrm{HCl} \text { solution }(\mathrm{mL}) \times 0.14 \times \text { dilutionfactor } \times 100}{\text { Sample weight }}
\end{aligned}
$$

\section{Statistical analysis}

The whole experiments were performed in triplicate. Results were expressed as means and standard deviations. All statistical analyses were performed using SPSS software program version 25.0 (SPSS Inc., Chicago, IL, USA). Statistical processing was carried out with two-way analysis of variance (ANOVA) using treatment groups (salt level and frozen temperature combinations) and frozen storage periods of sausage batters as factors. Since results of all experimental parameters had no interactions between treatments and frozen storage periods $(p>0.05)$, data were pooled by frozen storage periods and treatments. Duncan's multiple range test was performed as post ANOVA at significance level of 0.05 .

\section{RESULTS AND DISCUSSION}

\section{$\mathrm{pH}$ values and temperature of raw meat}

Table 2 shows $\mathrm{pH}$ values and temperature of raw meat state used to prepare PSs. As expected, $\mathrm{pH}$ values and temperatures of pre-rigor muscle were higher than those of postrigor one $(\mathrm{p}<0.05)$. Since pre-rigor muscle were deboned from carcass prior to rigor mortis, they had higher $\mathrm{pH}$ and temperature values than post-rigor muscle. According to 
Table 2. $\mathrm{pH}$ and temperature of raw meat as affected by different rigor state

\begin{tabular}{lcc}
\hline Item & Post-rigor & Pre-rigor \\
\hline $\mathrm{pH}$ & $5.66 \pm 0.10^{\mathrm{b}}$ & $6.20 \pm 0.09^{\mathrm{a}}$ \\
Temperature & $17.7 \pm 5.73^{\mathrm{b}}$ & $33.8 \pm 2.22^{\mathrm{a}}$ \\
\hline
\end{tabular}

${ }_{\mathrm{a}, \mathrm{b}}$ Means having the different superscripts in the same row are different $(p<0.05)$

Kim and Chin [9], $\mathrm{pH}$ values and temperatures of pre-rigor pork ham muscle were 6.06 and $29.2^{\circ} \mathrm{C}$, respectively, whereas those of post-rigor muscle were 5.69 and $11.0^{\circ} \mathrm{C}$, respectively. According to the previous study [9], pre-rigor muscle had higher $\mathrm{pH}$ and temperature values than post-rigor ones, similar to results of this study. Channon et al [10] reported that $\mathrm{pH}$ values and temperature of pork carcasses stunned with electrical stimulation were decreased from $40 \mathrm{~min}$ to 24 $\mathrm{hr}$ post slaughter. Since pre-rigor muscle did not go through postmortem, it had higher $\mathrm{pH}$ and temperature than postrigor one, and there was a metabolism causing a change in rigor state. During postmortem, $\mathrm{pH}$ decline is caused by glycolysis and the accumulation of lactate and hydrogen ions from the absence of the circulatory system due to the lack of oxygen [11].

\section{$\mathrm{pH}$ and color values of raw sausage batters}

As shown in Table 3, pH values of sausage batters using prerigor muscle were higher than those of post-rigor muscle. However, there were no differences in $\mathrm{pH}$ values between treatments within a same rigor state $(\mathrm{p}>0.05)$. This seems to be partially due to differences in $\mathrm{pH}$ values of raw meat state since the pre-rigor had normally higher $\mathrm{pH}$ than the postrigor. Raw sausage batters manufactured with pre-rigor muscle had higher $\mathrm{pH}$ than those manufactured with postrigor muscle, which was similar to $\mathrm{pH}$ trend in raw meat. Thus, sausages manufactured with pre-rigor muscle having high $\mathrm{pH}$ values would have higher $\mathrm{pH}$ than those manufactured with post-rigor muscle having lower $\mathrm{pH}$, even after curing. However, frozen storage did not affect $\mathrm{pH}$ values of the sausage batter, regardless of the frozen temperature $(\mathrm{p}>$ 0.05). Park et al [12] reported that $\mathrm{pH}$ values of fresh pork meat did not change during frozen storage at $-10^{\circ} \mathrm{C}(0,30$, 60,90 , and $120 \mathrm{~d}$ ), regardless of difference in retail cut (belly vs. loin) or packaging method (vacuum vs aerobic). These results indicated that frozen storage might not affect the $\mathrm{pH}$ vales of sausages before cooking ( $p>0.05)$.

Table 3 shows color values of raw sausage batters before cooking. There were no differences in any color parameters $\left(\mathrm{CIE} \mathrm{L} \mathrm{L}^{*}, \mathrm{a}^{*}\right.$, and $\left.\mathrm{b}^{*}\right)$ among treatments. CIE $\mathrm{L}^{*}$ and $\mathrm{b}^{*}$ values of sausage batters prior to freezing were higher than those of sausage batters after frozen storage for 4,8 , and 12 wks ( $\mathrm{p}<$ 0.05 ). However, CIE $\mathrm{a}^{*}$ values of sausage batters prior to freezing were lower than those after frozen treatments $(\mathrm{p}<$ 0.05 ). These results indicated that frozen storage might affect color values of raw sausage batters. The reason for such changes in color values of sausage batters after frozen storage might be due to depletion of cofactors. They would inhibit the change from myoglobin to metmyoglobin as oxidation progresses, resulting in reduced color stability and darkening [13].

\section{Protein solubility of raw sausage batter}

Protein solubility results of raw sausage batters are shown in Table 3 . There were no differences in protein solubility among all treatments ( $p>0.05)$. In general, it is known that meat protein with higher additional level of salt has higher protein solubility. Choi et al [14] reported that protein solubility of preblended pork for frankfurter added with the higher salt level (3.0\%) was higher than that of treatment with a lower level (1.5\%) of salt regardless of phosphate level. However, differences in protein solubility of sausage batter between salt levels of $1.0 \%$ and $1.5 \%$ were not observed due to differ-

Table 3. $\mathrm{pH}$, color values, and protein solubility of raw sausage batter as affected by different salt level, rigor state and frozen conditions

\begin{tabular}{|c|c|c|c|c|c|c|}
\hline Item & & $\mathrm{pH}$ & CIE L* & CIE a* & CIE $b^{*}$ & Protein solubility \\
\hline \multicolumn{7}{|l|}{ Treatment ${ }^{1)}$} \\
\hline \multirow[t]{2}{*}{ Salt 1.5\% } & Post-30 & $5.99 \pm 0.07^{b}$ & $56.8 \pm 0.99^{a}$ & $5.80 \pm 1.94^{\mathrm{a}}$ & $4.89 \pm 1.02^{\mathrm{a}}$ & $54.9 \pm 12.4^{a}$ \\
\hline & Post-70 & $5.95 \pm 0.05^{b}$ & $56.8 \pm 1.08^{a}$ & $5.80 \pm 1.69^{\mathrm{a}}$ & $5.09 \pm 0.70^{a}$ & $58.8 \pm 8.75^{a}$ \\
\hline \multirow[t]{2}{*}{ Salt $1.0 \%$} & Pre-30 & $6.26 \pm 0.13^{\mathrm{a}}$ & $57.7 \pm 1.39^{a}$ & $6.50 \pm 1.83^{\mathrm{a}}$ & $5.33 \pm 1.12^{a}$ & $50.5 \pm 7.64^{\mathrm{a}}$ \\
\hline & Pre-70 & $6.28 \pm 0.15^{\mathrm{a}}$ & $57.7 \pm 1.87^{\mathrm{a}}$ & $6.29 \pm 1.91^{\mathrm{a}}$ & $6.01 \pm 1.00^{\mathrm{a}}$ & $54.0 \pm 5.63^{\mathrm{a}}$ \\
\hline \multicolumn{7}{|c|}{ Storage time (wk) } \\
\hline 0 & & $6.16 \pm 0.20^{\mathrm{a}}$ & $58.7 \pm 0.92^{\mathrm{a}}$ & $3.40 \pm 1.04^{\mathrm{b}}$ & $6.99 \pm 1.73^{\mathrm{a}}$ & $58.8 \pm 12.4^{a}$ \\
\hline 4 & & $6.15 \pm 0.18^{a}$ & $56.2 \pm 1.22^{b}$ & $6.94 \pm 1.80^{a}$ & $5.48 \pm 1.52^{b}$ & $54.2 \pm 6.26^{a}$ \\
\hline 8 & & $6.13 \pm 0.20^{\mathrm{a}}$ & $57.0 \pm 1.13^{b}$ & $6.47 \pm 1.09^{a}$ & $5.59 \pm 1.09^{b}$ & $54.2 \pm 5.28^{a}$ \\
\hline 12 & & $6.14 \pm 0.19^{a}$ & $57.1 \pm 1.10^{b}$ & $6.59 \pm 0.90^{\mathrm{a}}$ & $5.45 \pm 1.05^{b}$ & $50.9 \pm 4.47^{\mathrm{a}}$ \\
\hline
\end{tabular}

1) $1.5 \%$, Post-30, pork sausage (PS) with $1.5 \%$ of salt using post-rigor muscle during batter storage at $-30^{\circ} \mathrm{C} ; 1.5 \%$, Post- 70 , PS with $1.5 \%$ of salt using post-rigor muscle during batter storage at $-70^{\circ} \mathrm{C} ; 1.0 \%$, Pre- 30 , PS with $1.0 \%$ of salt using pre-rigor muscle during batter storage at $-30^{\circ} \mathrm{C} ; 1.0 \%$, Pre- $70, \mathrm{PS}$ with $1.0 \%$ of salt using pre-rigor muscle during batter storage at $-70^{\circ} \mathrm{C}$

a,b Means having the different superscripts in the same column (treatment or storage time) are different $(p<0.05)$ 
ent rigor state in present study, resulting in similar protein solubility. Pre-rigor meat might have higher protein solubility than post-rigor one due to higher $\mathrm{pH}$ and ATP level, and functional properties such as water holding and emulsifying capacities of meat products using pre-rigor meat are also better than those using post-rigor one [15]. The solubilization of protein depends on $\mathrm{pH}$, ionic strength and temperature, and it is a process that includes the solvation, dissolution, wetting, and swelling of the protein molecule. It indicated that functionalities are greatly affected by protein solubility [16]. Therefore, meat protein using pre-rigor state might lead to acceptable processing quality even with a less salt level (1.0\%).

\section{pH and color values of cooked pork sausage}

Table 4 shows $\mathrm{pH}$ and color values of cooked PSs as affected by salt content and rigor state of raw meat during different frozen temperature. No differences in $\mathrm{pH}$ values of cooked PSs using pre-rigor and post rigor muscle at two different salt levels were observed between different frozen temperatures and storage period (12 wks) of raw sausage batters ( $\mathrm{p}>$ $0.05)$. Although $\mathrm{pH}$ values of cooked PSs using pre-rigor batters stored frozen at $-70^{\circ} \mathrm{C}$ (Pre-70) were higher than those of using post-rigor raw batter (Post-30 and Post-70), $\mathrm{pH}$ values of cooked sausage using pre-rigor batter stored frozen at $-30^{\circ} \mathrm{C}$ (Pre-70) were not different from those of Post-30 and Post-70 ( $\mathrm{p}>0.05)$. Pre-70 had a higher $\mathrm{pH}$ than sausage groups manufactured with post-rigor muscle due to sausage batter from pre-rigor muscle with higher $\mathrm{pH}$ values. Miller et al [17] reported that $\mathrm{pH}$ values of pork loin stored at $-17.8^{\circ} \mathrm{C}$ for 37 wks were not changed during frozen storage, resulting in maintaining $\mathrm{pH}$ values of muscle during frozen storage.

Color values of cooked PSs as affected by different rigor state, salt level, and frozen temperatures are shown in Table
4. These results indicated that the combination of rigor state and salt content did not affect color values of PS ( $p>0.05)$, as supported by Villamonte et al [18] who reported that chopped pork meat added with $1.5 \%$ and $3.0 \%$ of salt had similar lightness and redness values under the same additional level of phosphate. No differences in color values of PSs among different frozen storage periods of batters were also observed ( $>0.05)$. Van Laack et al [19] observed increases in redness values of cooked beef patties after $1 \mathrm{yr}$ of storage at $-27^{\circ} \mathrm{C}$. However, they did not explain the relationship between color change and frozen storage, which showed a different trend from the present study. The mechanism of color changes of cooked meat products during frozen storage is not fully understood yet, although many factors such as cooking methods and amount of metmyoglobin are known to affect color values. Thus, further research will be needed to understand fully how these factors affect color values of meat products [20].

\section{Texture profile analysis of cooked pork sausages}

As shown in Table 5, no differences in textural properties of cooked PSs among treatments were observed ( $p>0.05)$. Generally, meat products with higher additional levels of salt tend to have higher textural properties than those with lower salt contents. Thus, the reduction of salt content might negatively affect textural properties of meat products. JiménezColmenero et al [21] reported that low-fat cooked pork batter added with $2.5 \%$ of salt had higher textural properties than those added with $1.5 \%$ of salt. However, the addition levels of salt did not affect textural properties in the present study ( $p>0.05$ ). This might be due to differences in rigor states of raw meat to use in the manufacture of PSs, suggesting that meat products using pre-rigor muscle would show higher textural properties. Lee et al [22] reported that hardness, cohesiveness, gumminess, and chewiness of low-fat hot-boned pork gel was higher than those of chilled-boned one with

Table 4. $\mathrm{pH}$ and color values of cooked pork sausages as affected by different salt level, rigor state and frozen conditions

\begin{tabular}{|c|c|c|c|c|c|}
\hline Item & & $\mathrm{pH}$ & CIE L* & CIE a* & CIE b* \\
\hline \multicolumn{6}{|l|}{ Treatment ${ }^{1)}$} \\
\hline Salt 1.5\% & Post-30 & $6.21 \pm 0.05^{b}$ & $72.7 \pm 1.24^{\mathrm{a}}$ & $10.5 \pm 0.53^{\mathrm{a}}$ & $4.26 \pm 0.30^{a}$ \\
\hline \multirow[t]{2}{*}{ Salt 1.0\% } & Pre-30 & $6.34 \pm 0.27^{\mathrm{ab}}$ & $72.6 \pm 0.64^{a}$ & $11.1 \pm 0.50^{\mathrm{a}}$ & $4.99 \pm 0.64^{a}$ \\
\hline & Pre-70 & $6.45 \pm 0.11^{\mathrm{a}}$ & $72.7 \pm 0.91^{a}$ & $10.9 \pm 0.44^{\mathrm{a}}$ & $5.05 \pm 0.70^{a}$ \\
\hline \multicolumn{6}{|c|}{ Storage time (wk) } \\
\hline 4 & & $6.34 \pm 0.14^{\mathrm{a}}$ & $73.1 \pm 0.81^{a}$ & $10.5 \pm 0.37^{a}$ & $4.74 \pm 0.69^{a}$ \\
\hline 8 & & $6.25 \pm 0.26^{a}$ & $72.3 \pm 0.65^{a}$ & $10.8 \pm 0.43^{a}$ & $4.50 \pm 0.71^{a}$ \\
\hline 12 & & $6.32 \pm 0.11^{\mathrm{a}}$ & $72.4 \pm 1.03^{a}$ & $11.0 \pm 0.59^{a}$ & $4.61 \pm 0.56^{a}$ \\
\hline
\end{tabular}

1) $1.5 \%$, Post- 30 , pork sausage (PS) with $1.5 \%$ of salt using post-rigor muscle during batter storage at $-30^{\circ} \mathrm{C} ; 1.5 \%$, Post- 70 , PS with $1.5 \%$ of salt using post-rigor muscle during batter storage at $-70^{\circ} \mathrm{C} ; 1.0 \%$, Pre- 30 , PS with $1.0 \%$ of salt using pre-rigor muscle during batter storage at $-30^{\circ} \mathrm{C} ; 1.0 \%$, Pre- $70, \mathrm{PS}$ with $1.0 \%$ of salt using pre-rigor muscle during batter storage at $-70^{\circ} \mathrm{C}$.

$a, b$ Means having the different superscripts in the same column (treatment or storage time) are different $(p<0.05)$. 
Table 5. Texture properties of cooked pork sausages as affected by different salt level, rigor state and frozen conditions

\begin{tabular}{|c|c|c|c|c|c|c|}
\hline Item & & Hardness & Springiness & Gumminess & Chewiness & Cohesiveness \\
\hline \multicolumn{7}{|l|}{ Treatment ${ }^{1)}$} \\
\hline \multirow[t]{2}{*}{ Salt 1.5\% } & Post-30 & $4,418 \pm 493^{a}$ & $6.18 \pm 0.72^{\mathrm{a}}$ & $36.6 \pm 4.75^{\mathrm{a}}$ & $220 \pm 33.4^{a}$ & $0.01 \pm 0.00^{\mathrm{a}}$ \\
\hline & Post-70 & $5,015 \pm 519^{a}$ & $5.96 \pm 0.76^{\mathrm{a}}$ & $49.7 \pm 16.1^{\mathrm{a}}$ & $290 \pm 79.5^{\mathrm{a}}$ & $0.01 \pm 0.00^{\mathrm{a}}$ \\
\hline \multirow[t]{2}{*}{ Salt $1.0 \%$} & Pre-30 & $4,740 \pm 821^{\mathrm{a}}$ & $5.40 \pm 0.49^{a}$ & $45.7 \pm 12.4^{\mathrm{a}}$ & $244 \pm 73.1^{\mathrm{a}}$ & $0.01 \pm 0.00^{\mathrm{a}}$ \\
\hline & Pre-70 & $4,853 \pm 736^{a}$ & $5.36 \pm 0.72^{\mathrm{a}}$ & $44.3 \pm 13.3^{\mathrm{a}}$ & $247 \pm 77.5^{\mathrm{a}}$ & $0.01 \pm 0.00^{\mathrm{a}}$ \\
\hline \multicolumn{7}{|c|}{ Storage time (wk) } \\
\hline 0 & & $4,825 \pm 443^{a}$ & $5.70 \pm 0.35^{\mathrm{a}}$ & $42.9 \pm 4.99^{\mathrm{a}}$ & $243 \pm 26.5^{a}$ & $0.01 \pm 0.00^{\mathrm{a}}$ \\
\hline 4 & & $4,934 \pm 499^{a}$ & $5.63 \pm 0.95^{\mathrm{a}}$ & $50.4 \pm 9.97^{a}$ & $273 \pm 65.7^{a}$ & $0.01 \pm 0.00^{\mathrm{a}}$ \\
\hline 8 & & $4,530 \pm 858^{a}$ & $5.33 \pm 0.46^{\mathrm{a}}$ & $38.3 \pm 8.45^{\mathrm{a}}$ & $215 \pm 58.3^{a}$ & $0.01 \pm 0.00^{\mathrm{a}}$ \\
\hline 12 & & $4,738 \pm 816^{a}$ & $6.23 \pm 0.84^{\mathrm{a}}$ & $44.8 \pm 20.8^{\mathrm{a}}$ & $269 \pm 104^{a}$ & $0.01 \pm 0.00^{\mathrm{a}}$ \\
\hline
\end{tabular}

1) $1.5 \%$, Post-30, pork sausage (PS) with $1.5 \%$ of salt using post-rigor muscle during batter storage at $-30{ }^{\circ} \mathrm{C} ; 1.5 \%$, Post- 70 , PS with $1.5 \%$ of salt using post-rigor muscle during batter storage at $-70^{\circ} \mathrm{C} ; 1.0 \%$, Pre-30, PS with $1.0 \%$ of salt using pre-rigor muscle during batter storage at $-30^{\circ} \mathrm{C} ; 1.0 \%$, Pre- $70, \mathrm{PS}$ with $1.0 \%$ of salt using pre-rigor muscle during batter storage at $-70^{\circ} \mathrm{C}$.

${ }^{a}$ Means having the different superscripts in the same column (treatment or storage time) are different $(p<0.05)$.

the same fat content. Despite differences in addition levels of salt, the rigor state might affect textural properties, resulting in similar textural properties with a combination effect. However, no changes in textural properties of cooked sausages were observed during the frozen storage period for 12 wks in the present study ( $>>0.05)$. According to a study of Kim and Chin [9], hardness and gumminess of PS using raw meat stored under frozen were lower than those using fresh meat due to muscle denaturation during frozen. It is generally accepted that during the process of freezing and thawing, myofibrillar protein is denatured, leading to deformation of existing regular and continuous microstructure [23]. In contrast, an interesting finding in this study was that frozen storage of raw sausage batter did not affect textural properties of cooked sausage, regardless of the frozen temperature and time.

\section{Cooking loss and expressible moisture of cooked sausages}

As shown in Table 6, there were no differences in Cooking loss (CL, \%) of cooked PSs among treatments ( $>0.05)$. This result could be explained by the fact that reduced-salt sausage products were redeemed with pre-rigor muscle in terms of WHC. Kang et al [24] reported that CLs of raw sausage batters added with $2 \%$ salt were higher than those added with $1 \%$ salt. It indicated that CLs of PSs with lower salt contents $(\leq 1.0 \%)$ were higher than those with higher salt contents because salt increased WHC and decreased CLs in meat products. The addition of sodium chloride caused swelling of myofibrillar proteins by increase negative charges [4]. This means that the side chains of the amino acids in net charge of proteins bind water molecules by ionic strength of chloride. Despite different addition levels of salt, all treatments had similar CLs due to different rigor state, which could

Table 6. Cooking loss, expressible moisture, TBARS, and VBN values of pork sausages as affected by different salt level, rigor state and frozen conditions

\begin{tabular}{|c|c|c|c|c|c|}
\hline Item & & $\mathrm{CL}$ & EM & TBARS & VBN \\
\hline \multicolumn{6}{|l|}{ Treatment ${ }^{1)}$} \\
\hline Salt 1.5\% & Post-30 & $29.1 \pm 1.90^{b}$ & $5.85 \pm 2.11^{\mathrm{a}}$ & $0.26 \pm 0.01^{a}$ & $2.00 \pm 0.13^{a}$ \\
\hline \multirow[t]{2}{*}{ Salt $1.0 \%$} & Pre-30 & $31.2 \pm 1.87^{\mathrm{ab}}$ & $7.07 \pm 2.53^{\mathrm{a}}$ & $0.26 \pm 0.01^{\mathrm{a}}$ & $2.02 \pm 0.12^{a}$ \\
\hline & Pre-70 & $31.7 \pm 2.87^{a}$ & $6.06 \pm 0.68^{a}$ & $0.25 \pm 0.01^{a}$ & $1.95 \pm 0.00^{\mathrm{a}}$ \\
\hline \multicolumn{6}{|c|}{ Storage time (wks) } \\
\hline 4 & & $6.37 \pm 1.73^{\mathrm{a}}$ & $31.0 \pm 2.74^{\mathrm{a}}$ & $0.26 \pm 0.01^{\mathrm{a}}$ & $1.98 \pm 0.10^{a}$ \\
\hline 8 & & $6.26 \pm 1.24^{\mathrm{a}}$ & $30.9 \pm 2.15^{\mathrm{a}}$ & $0.26 \pm 0.01^{a}$ & $2.00 \pm 0.08^{a}$ \\
\hline 12 & & $6.66 \pm 2.70^{\mathrm{a}}$ & $31.9 \pm 3.32^{\mathrm{a}}$ & $0.26 \pm 0.01^{a}$ & $2.02 \pm 0.08^{a}$ \\
\hline
\end{tabular}

CL, cooking loss; EM, expressible moisture; TBARS, thiobarbituric acid reactive substances; VBN, volatile basic nitrogen.

1) $1.5 \%$, Post- 30 , pork sausage (PS) with $1.5 \%$ of salt using post-rigor muscle during batter storage at $-30^{\circ} \mathrm{C} ; 1.5 \%$, Post- 70 , PS with $1.5 \%$ of salt using post-rigor muscle during batter storage at $-70^{\circ} \mathrm{C} ; 1.0 \%$, Pre- 30 , PS with $1.0 \%$ of salt using pre-rigor muscle during batter storage at $-30^{\circ} \mathrm{C} ; 1.0 \%$, Pre- $70, \mathrm{PS}$ with $1.0 \%$ of salt using pre-rigor muscle during batter storage at $-70^{\circ} \mathrm{C}$.

$a, b$ Means having the different superscripts in the same column are different $(p<0.05)$ 
compensate for reduced-sodium sausage products. Hamm [25] observed that CLs of homogenize beef neck muscle with salt tended to be increased as the $\mathrm{pH}$ declines from 6.8 to 5.4 until rigor mortis. It indicated that $\mathrm{pH}$ fall could occur to decrease WHC of muscles, and as the $\mathrm{pH}$ of meat reaches the isoelectric point ( $\mathrm{pH}$ 5.4), the WHC of muscle decreases due to net charge effect of protein between positive and negative charges [26]. This study indicated that pre-rigor muscle could have higher WHC based on initial high $\mathrm{pH}$ values of the rigor state. Although CLs of PSs with a lower salt level were increased, when pre-rigor muscle were used, then they might compensate for the water loss of muscle in low or reduced-salt sausages during cooking and storage.

Expressible moisture (EM, \%) results of cooked sausages as affected by salt content, rigor state, and different frozen conditions of sausage batters are shown in Table 6. No differences in EM (\%) values of PSs were observed among treatments ( $p>0.05)$. There was no difference in EM values between Pre-30 and Pre-70 ( $>00.05)$. Post-70 with a higher salt level (1.5\%) and Pre-30 and Pre-70 with a reduced salt level $(1.0 \%)$ had similar EM values $(\mathrm{p}>0.05)$. These results indicated that PSs manufactured using pre-rigor muscle with reduced-salt level had EM similar to those of Post-70 (post-rigor) with a high salt content (1.5\%). Although PSs added with a high salt content had higher WHC in a previous study [27], no differences in EM between Post-30 or Post-70 with $1.5 \%$ salt and Pre-30 with $1.0 \%$ salt were observed. Honikel and Hamm [28] reported that WHC of prerigor muscle was higher than those of post-rigor ones as measured by filter paper press method. There were no differences in EM of cooked sausages according to the frozen storage period of sausage batters before heating ( $p>0.05$ ). These results suggested that frozen storage of sausage batter might not affect WHC of the final products, if both rigor-state and salt combination were applied properly in the manufacture of processed meats.

\section{Thiobarbituric acid reactive substances of cooked sausages}

Table 6 shows TBARS results of cooked sausages with different rigor states of raw meat, salt content, and frozen storage temperature of raw batter. No differences in TBARS values among all treatments during storage were observed ( $p>0.05$ ). This indicated that different salt contents, rigor states of raw meat, and frozen conditions of raw batter did not affect TBARS values of cooked sausages. Drerup et al [29] reported that TBARS values of pre-rigor fresh PSs were lower than those of post-rigor PSs with the same salt level during storage at $0^{\circ} \mathrm{C}$. This suggested that TBARS were highly related to the $\mathrm{pH}$ of raw meat. There was a slow lipid oxidation in pre-rigor processing. Unlike the previous study, the use of pre-rigor muscle and its $\mathrm{pH}$ value did not affect TBARS of PSs during frozen storage, regardless of storage temperature.

Volatile basic nitrogen ( $\mathrm{mg} \%$ ) of cooked sausages

As shown in Table 6, no differences were observed in VBN values of PSs prepared using rigor states of raw meat added with different salt contents during frozen storage $(p>0.05)$. In a previous study of Kim and Chin [9], VBN values of PSs prepared with pre-rigor muscle added with $0.5 \%, 1.0 \%$, and $1.5 \%$ of salt levels were not different from those of sausages using post-rigor one ( $1.5 \%$ salt). These results suggested that the no differences in VBN values were partially due to proper combination effect of salt level (1.0\% vs $1.5 \%)$ and the rigor state of raw meat (pre-rigor vs. post-rigor muscle). Kim et al [30] reported that there was no difference in VBN between fresh pork loin and frozen-and-thawed one during storage. These results indicated that freezing and thawing of raw sausage batters did not affect VBN values of final sausage products, if frozen conditions of sausage batters were controlled properly.

\section{CONCLUSION}

Although pre-rigor PSs contained the lower salt level (1.0\%), most of their quality characteristics were similar to those of post-rigor PSs with the higher salt level (1.5\%). It indicated that pre-rigor pork ham would have great processing aptitude based on high $\mathrm{pH}$ for the manufacture of reduced-sodium meat products. In addition, different frozen storage temperatures $\left(-30^{\circ} \mathrm{C}\right.$ vs $\left.-70^{\circ} \mathrm{C}\right)$ of raw sausage batter had no effect on quality characteristics of pre-rigor PSs. Therefore, prerigor muscle and frozen storage of sausage batter might be useful in the improvement of quality characteristics in the processing of reduced-sodium meat products.

\section{CONFLICT OF INTEREST}

We certify that there is no conflict of interest with any financial organization regarding the material discussed in the manuscript.

\section{FUNDING}

This study was supported by a project (\#PJ013809022019) funded by the Rural Development Administration, Republic of Korea.

\section{REFERENCES}

1. Doyle ME, Glass KA. Sodium reduction and its effect on food safety, food quality, and human health. Comprehensive reviews in food science and food safety. Compr Rev Food Sci Food Saf 2010;9:44-56. https://doi.org/10.1111/j.1541- 


\subsubsection{6.x}

2. Desmond E. Reducing salt: A challenge for the meat industry. Meat Sci 2006;74:188-96. https://doi.org/10.1016/j.meatsci. 2006.04.014

3. Xiong YL. Myofibrillar protein from different muscle fiber types: implications of biochemical and functional properties in meat processing. Crit Rev Food Sci Nutr 1994;34:293-320. https://doi.org/10.1080/10408399409527665

4. Ruusunen M, Puolanne E. Reducing sodium intake from meat products. Meat Sci 2005;70:531-41. https://doi.org/ 10.1016/j.meatsci.2004.07.016

5. Puolanne EJ, Terrell RN. Effects of rigor-state, levels of salt and sodium tripolyphosphate on physical, chemical and sensory properties of frankfurter-type sausages. J Food Sci 1983;48:1036-8. https://doi.org/10.1111/j.1365-2621.1983. tb09155.x

6. Claus JR, Sørheim O. Preserving pre-rigor meat functionality for beef patty production. Meat Sci 2006;73:287-94. https:// doi.org/10.1016/j.meatsci.2005.12.004

7. Sinnhuber RO, Yu TC. The 2-thiobarbituric acid reaction, an objective measure of the oxidative deterioration occurring in fats and oils. J Oleo Sci 1977;26:259-67. https://doi.org/ 10.5650/jos1956.26.259

8. Conway EJ. Determination of volatile amines. In: Conway EJ, editor. Microdiffusion analysis and volumetric error. London, UK: Crosby Lockwood; 1947. pp. 195-200.

9. Kim GH, Chin KB. Quality characteristics of reduced-salt pork sausages using fresh and frozen pre-rigor muscle. J Korean Soc Food Sci Nutr 2019;48:1383-90. https://doi.org/ 10.3746/jkfn.2019.48.12.1383

10. Channon HA, Payne AM, Warner RD. Halothane genotype, pre-slaughter handling and stunning method all influence pork quality. Meat Sci 2000;56:291-9. https://doi.org/10.1016/ S0309-1740(00)00056-5

11. Stephens JW, Dikeman ME, Unruh JA, Haub MD, Tokach MD. Effects of pre-rigor injection of sodium citrate or acetate, or post-rigor injection of phosphate plus salt on post-mortem glycolysis, pH, and pork quality attributes. Meat Sci 2006;74; 727-37. https://doi.org/10.1016/j.meatsci.2006.05.025

12. Park SY, Yoo SS, Uh JH, et al. Evaluation of lipid oxidation and oxidative products as affected by pork meat cut, packaging method, and storage time during frozen storage $\left(-10^{\circ} \mathrm{C}\right) . \mathrm{J}$ Food Sci 2007;72;114-9. https://doi.org/10.1111/j.1750-3841. 2006.00265.x

13. Boles JA, Pegg R. Meat color [Internet]. Saskatoon, Canada: University of Saskatchewan; c2010 [cited 2021 Aug 18]. Available from: http://safespectrum.com/pdfs/meatcolor.pdf

14. Choi YI, Kastner CL, Kropf DH. Effects of hot boning and various levels of salt and phosphate on protein solubility, functionality, and storage characteristics of preblended pork used in frankfurters. J Food Prot 1987;50:1025-36. https:// doi.org/10.4315/0362-028X-50.12.1025
15. Pisula A, Tyburcy A. Hot processing of meat. Meat Sci 1996; 43:125-34. https://doi.org/10.1016/0309-1740(96)00060-5

16. Chou DH, Morr CV. Protein-water interactions and functional properties. J Am Oil Chem' Soc 1979;56:A53-A62. https:// doi.org/10.1007/BF02671785

17. Miller AJ, Ackerman SA, Palumbo SA. Effects of frozen storage on functionality of meat for processing. J Food Sci 1980;45:1466-71. https://doi.org/10.1111/j.1365-2621.1980. tb07541.x

18. Villamonte G, Simonin H, Duranton F, Chéret R, De Lamballerie M. Functionality of pork meat proteins: Impact of sodium chloride and phosphates under high-pressure processing. Innov Food Sci Emerg Technol 2013;18:15-23. https:// doi.org/10.1016/j.ifset.2012.12.001

19. Van Laack RLJM, Berry BW, Solomon MB. Variations in internal color of cooked beef patties. J Food Sci 1996;61:410-4. https://doi.org/10.1111/j.1365-2621.1996.tb14205.x

20. King NJ, Whyte R. Does it look cooked? A review of factors that influence cooked meat color. J Food Sci 2006;71:R31-40. https://doi.org/10.1111/j.1750-3841.2006.00029.x

21. Jiménez-Colmenero F, Fernandez P, Carballo J, Fernández Martín F. High-pressure-cooked low-fat pork and chicken batters as affected by salt levels and cooking temperature. J Food Sci 1998;63:656-9. https://doi.org/10.1111/j.1365-2621. 1998.tb15806.x

22. Lee HC, Wonderly MP, Pokharel S, et al. Cold-batter mincing of hot-boned and crust-freeze-air-chilled ham muscle reduced fat content in protein gels. Int J Food Sci Technol 2020;55: 3267-77. https://doi.org/10.1111/ijfs.14589

23. Jiménez-Colmenero F, Carballo J, Solas MT. The effect of use of freeze-thawed pork on the properties of Bologna sausages with two fat levels. Int J Food Sci Technol 1995;30;335-45. https://doi.org/10.1111/j.1365-2621.1995.tb01382.x

24. Kang ZL, Li B, Ma HJ, Chen FS. Effect of different processing methods and salt content on the physicochemical and rheological properties of meat batters. Int J Food Prop 2016;19: 1604-15. https://doi.org/10.1080/10942912.2015.1105819

25. Hamm R. Post-mortem changes in muscle with regard to processing of hot-boned beef. Acta Aliment Pol 1982;8: 235-54.

26. Huff-Lonergan E. Fresh meat water-holding capacity. In: Kerry JP, Ledward D. editors. Improving the sensory and nutritional quality of fresh meat. Sawston, UK: Woodhead Publishing; 2009. p. 147-60. https://doi.org/10.1533/978184 5695439.1.147

27. Puolanne EJ, Ruusunen MH, Vainionpää JI. Combined effects of $\mathrm{NaCl}$ and raw meat $\mathrm{pH}$ on water-holding in cooked sausage with and without added phosphate. Meat Sci 2001;58:1-7. https://doi.org/10.1016/S0309-1740(00)00123-6

28. Honikel KO, Hamm R. Measurement of water-holding capacity and juiciness. In: Pearson AM, Dutson TR editors. Quality attributes and their measurement in meat, poultry 
and fish products. Boston MA, USA: Springer; 1994. pp. $125-61$.

29. Drerup DL, Judge MD, Aberle ED. Sensory properties and lipid oxidation in prerigor processed fresh pork sausage. J Food Sci 1981;46:1659-61. https://doi.org/10.1111/j.1365- 2621.1981.tb04456.x

30. Kim J, Park SH, Choi DS, et al. Effects of ultrasonic thawing on the physicochemical properties of frozen pork. Korean J Food Preserv 2017;24:230-6. https://doi.org/10.11002/kjfp. 2017.24.2.230 